\title{
Geology, seismic activity and groundwater conditions at six potential disposal sites for radioactive waste from Risø, Denmark
}

\author{
Peter Gravesen, Bertel Nilsson, Merete Binderup, Tine B. Larsen and Stig A. Schack Pedersen
}

In 2003 it was decided by the Danish Parliament that lowand intermediate-level radioactive waste from the Danish nuclear research facility, Risø, is to be stored at a permanent disposal site (Ministeriet for Sundhed og Forebyggelse 2008; Gravesen et al.2012a). Both the issue of storage and the selection of potential sites have caused considerable public debate. In this paper we report on the most recent geological investigations intended to further improve the data base for the selection and decision process, although no conclusions have been drawn at this stage.

The waste might be deposited on the land surface, partly below surface or totally below surface, and pre-Quaternary rocks and deposits are the main general targets. In 2011 six potential areas were selected for further studyd and evaluation of their suitability for disposal of radioactive waste. The study evaluated local groundwater conditions and earthquake hazards, infrastructure, wildlife, environment, water supply (especially drinking water) and heritage monuments (Gravesen et al. 2011, 2012b). The new studies of the six po- tential sites and their surroundings were performed by the Geological Survey of Denmark and Greenland aided by the Danish Nature Agency (Naturstyrelsen), and included drilling of several new boreholes.

\section{Geological setting}

The areas that were chosen for further study were selected from 22 initial targets (Gravesen et al. 2011) based on compliance with specific criteria (see below) that had previously been established from geological models (Gravesen et al. 2012a). The six selected areas (Fig. 1) are located in different geological settings. The Østermarie-Paradisbakkerne area on Bornholm consists of Precambrian Paradisbakke migmatite and Bornholm gneiss. In the Rødbyhavn area on Lolland, Palaeocene clay rests on Maastrichtian chalk, while the Kertinge Mark area on Fyn comprises thick Palaeocene clay deposits overlying Danian Limestone. In the Hvidbjerg area of north-west Jylland, Palaeocene and Eocene clay for-
Fig. 1. Map of Denmark showing the locations of the six areas selected for detailed studies of their suitability as disposal sites for radioactive waste from Risø.

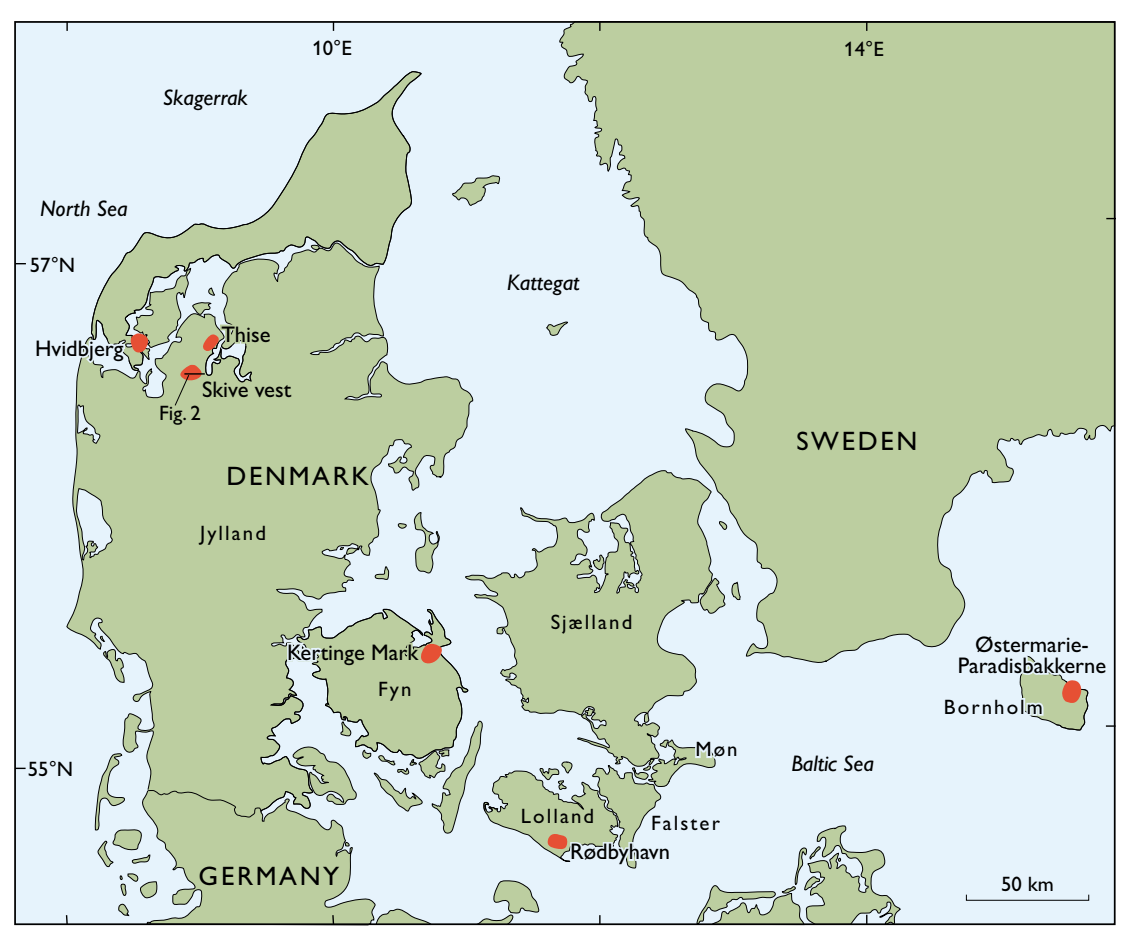






Fig. 2. Geological cross section through Palaeogene-Neogene deposits of the Skive vest area, extending from Rettrup in the west to Skive in the east. The positions of the boreholes with DGU numbers are indicated along the top of the figure.

mations rest on Danian Limestone and are covered by Oligocene and Miocene clay formations. Farther to the east and south-east, at Thise and Skive vest (west), Oligocene and Miocene clay, respectively, are present. Quaternary clayey till overlies the pre-Quaternary rocks and sediments at all sites.

\section{Collection of seismic, borehole and groundwater data}

Part of the new study consisted of an evaluation of earthquake potential. The seismic activity in Denmark has been recorded instrumentally since 1929 , and in later years by an interconnected network of seismic stations in Denmark and surrounding countries. Older earthquakes were examined from descriptions in the literature. For the three potential sites on Bornholm, Lolland and Fyn available seismic data within a radius of $50 \mathrm{~km}$ were evaluated. For the three areas in north-west Jylland a radius of $75 \mathrm{~km}$ was used.

In the new study additional boreholes were drilled in each of the six selected areas. Sediment samples were collected from each metre and analysed, and several types of continuous geophysical logs were performed in most boreholes. Such logs are particularly useful for extrapolations between the samples. On Bornholm, eight existing water abstraction wells for domestic use were logged for idenfication of fractures in the bedrock.

Evaluation of groundwater, drinking water and water supplies was based on new information and existing literature, as well as local knowledge of potential groundwater problems. The latter was obtained by interviewing local specialists and acquisition of written accounts and other information collected by the local authorities.

\section{Survey results}

Data from the borehole samples and from the geophysical logs have provided important new information on the geological models of the investigated areas, which comprise data on lithology and stratigraphy as well as tectonic and sedimentological structures. All the relevant information has been compiled into six technical reports by the Geological Survey of Denmark and Greenland, which are available at GEUS' website, http://www.geus.dk/program-areas/natureenvironment/denmark/radioaktivt_affald/index-dk.htm. The main topics are: boreholes and logging, seismic activity and earthquakes, groundwater and drinking water, climate and climate changes and local planning (infrastucture, wildlife, environment, cultural heritage, raw materials, agriculture and water supply structure). All this information will be used in the ongoing evaluation of the areas and identification of the two most suitable areas. In this paper only selected results are presented, including geological traverses through the six areas.

\section{Geological data}

The Precambrian crystalline rocks on Bornholm are thick and extensive and contain a network of fractures. Knowledge of the fracture systems in the Østermarie-Paradisbakkerne area is important for evaluation of groundwater flow and storage, and for evaluation of the stability of the host rocks. Horizontal and vertical fractures to a depth of $12 \mathrm{~m}$ can be observed in quarries. The number of horizontal fractures appears to decrease downwards, while their spacing increases. This is a normal observation in the uppermost crust. The geophysical borehole logs comprise natural gamma-ray, resistivity, sound velocity, fluid temperature, fluid conductivity and flow logs, which can be used to document fractures at various levels from $20 \mathrm{~m}$ below the surface down to a depth 
Fig. 3. Earthquake epicentres in the north-west Jylland region. The magnitude on the Richter scale is shown by the size of the dots (from Gravesen et al. 2012b). Other earthquake epicentres in the Danish region are not shown on this map.

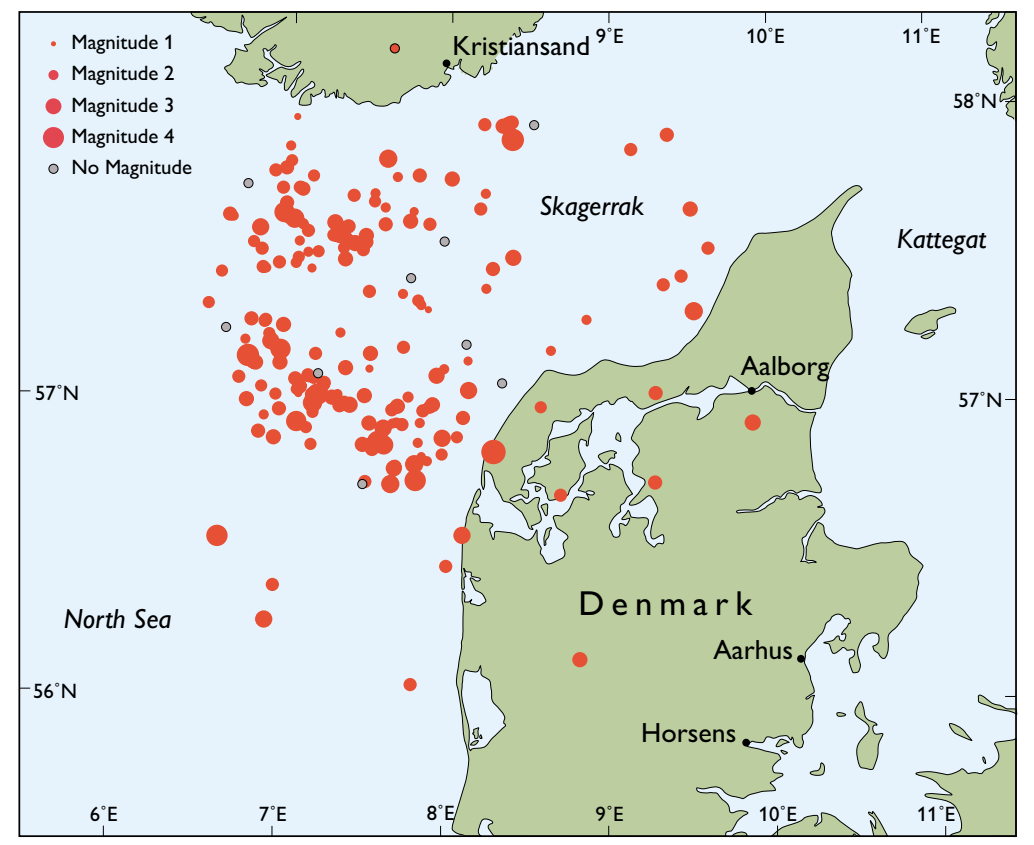

of $90 \mathrm{~m}$. Extrapolations of the borehole data suggest that some fractures are horizontal or subhorizontal and connected over larger distances. Quaternary clayey and sandy tills on Bornholm are mostly only a few metres thick.

The pre-Quaternary rocks and deposits throughout the remaining parts of Denmark are fine-grained, have low permeability, and are covered by Quaternary clayey tills. The clay deposits are generally relatively thick and appear to be of wide horizontal distribution within the selected areas, reflecting the fact that the deposits represent marine depositional environments. Furthermore, the deposits are characterised by low degrees of glaciotectonic disturbance and pre-Quaternary tectonic movements. These characteristics meet the criteria described by Gravesen et al. (2011, 2012a) based on the guidelines of the International Atomic Energy Agency (IAEA 1994).

At Rødbyhavn, Palaeocene fine-grained deposits and plastic clay from the Æbelø and Holmehus Formations resting on Maastrichtian chalk have been documented from geophysical surveys and boreholes drilled for bentonite exploration and geotechnical purposes related to the Femern Bælt Fixed Link. The characteristics of the $c .80 \mathrm{~m}$ thick clay sequence and the overlying up to $40 \mathrm{~m}$ thick hard Quaternary clayey till demonstrate that the deposits are in situ, although tectonic disturbances are known to exist outside the area.

Within and just outside the Kertinge Mark area, up to 75 m thick Palaeocene Kerteminde Marl and Æbelø Formation overlying Danian limestone have been documented. The new boreholes demonstrate that non-calcareous black clay of the Æbelø Formation occurs above calcareous grey clay of the Kerteminde marl in the northern part of the Kertinge Mark peninsula, forming the natural stratigraphical sequence. Quaternary clayey till up to $40 \mathrm{~m}$ thick is found above these formations. Some layers are very sandy and gravelly as shown by samples from the boreholes and from geophysical logs.

In the Hvidbjerg area, Palaeocene and Eocene grey clay of the Kerteminde Marl and diatomite from the Fur Formation rest on Danian Limestone on the northern flank of the Uglev salt diapir. The formations are covered by Oligocene and Miocene black-brown mica clay deposits from the Brejning and Vejle Fjord Formations, with a total of up to $100 \mathrm{~m}$ thickness. Thick Quaternary clayey till comprises the top $20 \mathrm{~m}$. The new borehole demonstrates a more complex buildup of the succession with unconformities caused by tectonic episodes and erosion.

In the Thise area, more than $100 \mathrm{~m}$ thick layers of Oligocene mica clay from the Brejning Formation and green-grey, fine-grained clay from the Branden clay unit are covered by up to $18 \mathrm{~m}$ thick Quaternary clayey till. The new borehole penetrated $22 \mathrm{~m}$ of Brejning Formation below $19 \mathrm{~m}$ of Quaternary clayey till. The Oligocene deposits form an erosional inlier bordered by buried valleys filled with Quaternary till and meltwater deposits.

In the Skive vest area, up to $100 \mathrm{~m}$ of Oligocene and Miocene deposits of fine-grained grey Skive Clay unit (to the east) and black-brown mica clay from the Brejning and Vejle Fjord Formations (to the west) are present; the layers dip slightly to the west (Fig. 2). Two new boreholes penetrated the two youngest formations down to $50 \mathrm{~m}$ below the sur- 
face, possibly indicating that the two formations are found in situ as also indicated by other borehole data in the area. A thin cover of Quaternary clayey till is present.

\section{Seismic activity and earthquakes}

The seismic activity in most of Denmark is low, but a little higher in north-west Jylland than in other parts of the country. The most seismically active region relevant for the current investigation is located in Skagerrak and the North Sea, while epicentres on land are rare (Fig. 3). The earthquake magnitudes are low, with values mainly below 3 on the Richter scale.

No epicentres are found on Bornholm, although some occur in the nearshore areas of the Baltic Sea. Bornholm has not been seismically active in recent historical time, although an earthquake in 1875 possibly had its epicentre on west Bornholm. Small earthquakes in the Baltic Sea and southern Sweden can sometimes be registered on Bornholm. According to instrumental and historical sources, Lolland does not seem to be seismically active, and the seismicity on Fyn is very low. Some minor earthquakes have been measured on Fyn, but the historical literature does not suggest any earthquake activity.

A slightly higher seismicity is found in north-west Jylland around Hvidbjerg, Thise and Skive vest, since many small earthquakes located in the North Sea and Skagerrak are registered on land. Historical literature also suggests many small earthquakes around these three areas, and some damage to buildings has occurred. An earthquake in 1841 is probably the largest earthquake registered in Denmark.

\section{Groundwater conditions and drinking water}

All six areas are situated outside areas of Special Drinking Water Interests (OSD), which are the most important Danish supply areas for drinking water. Major regional groundwater reservoirs are also absent, although some small reservoirs are important for local supplies.

On Bornholm the basement rocks form a fractured groundwater reservoir with restricted groundwater flow at various levels. The reservoir has a limited yield but is used locally in an area where connection to public water utilities is difficult and costly.

The Rødbyhavn area is almost totally devoid of groundwater reservoirs, although some surface water is extracted for drinking purposes. The Kertinge Mark area also lacks groundwater reservoirs, but local aquifers close to the sur- face are used for water supply. Just south-east of this area, groundwater reservoirs in an OSD area supply the town of Kerteminde with drinking water. The reservoir is small and vulnerable because of its restricted size and thickness, and no alternative sources exist in the neighbourhood.

In the Hvidbjerg area, almost no goundwater is pumped because groundwater reservoirs are lacking. The Thise area has some local abstraction from thin meltwater sand reservoirs. An area which is particularly vulnerable to nitrate contamination (NFI) occurs east of Thise waterworks. Just east and north of the area, OSD areas with sand reservoirs are found in buried valleys. Throughout the Skive vest area, local water supplies use sand and gravel reservoirs; no public or private water utilities are found.

\section{Final remarks}

The present investigations of the geology, earthquake risks, groundwater and drinking water conditions are crucial for the selection of two areas for further examination before a final disposal site can be chosen. Before the selection of the two areas an Environmental Impact Assessment (EIA) has to be performed. Also the possibilities of export of the waste to a foreign country have to be investigated. Finally the design and establishment of a temporary disposal for the waste have to be described and evaluated.

\section{Acknowledgement}

Financial support was provided by the Parliament of Denmark.

\section{References}

Gravesen, P., Nilsson, B., Pedersen, S.A.S. \& Binderup, M. 2011: Low- and intermediate level radioactive waste from Risø, Denmark. Location studies for potential disposal areas. Report no. 11. Områdebeskrivelser - Description of areas. Geological Survey of Denmark and Greenland Report 2011/51, 64 pp.

Gravesen, P., Binderup, M., Nilsson, B. \& Pedersen, S.A.S. 2012a: Geological characterisation of potential disposal areas for radioactive waste from Risø, Denmark. Geological Survey of Denmark and Greenland Bulletin 23, 21-24.

Gravesen, P., Nilsson, B., Binderup, M. Larsen, T. \& Pedersen, S.A.S. 2012b: Lav- og mellem radioaktivt affald fra Risø, Danmark. Omegnsstudier. Rapport nr. 5. Område Thise, Skive Kommune. Geological Survey of Denmark and Greenland Report 2012/127, 81 pp.

IAEA 1994: Siting of near surface disposal facilities. Safety guides. Safety Series 111-G-3.1, 37 pp.

Ministeriet for Sundhed og Forebyggelse 2008: Beslutningsgrundlag for et dansk slutdepot for lav- og mellemaktivt affald, 47 pp. København: Ministeriet for Sundhed og Forebyggelse. 